\title{
Study on the Effective Method to Enhance the Soft Power of Vocational Education
}

\author{
Jing Jiang ${ }^{1}$ \\ ${ }^{1}$ Liaoning Police College, Dalian, Liaoning, 116036 \\ hunter2011@foxmail.com
}

Keywords: Vocational Education; Soft Power; Innovation; Campus Culture; Brand

\begin{abstract}
Soft power has been widespread concern around the world by political leaders, experts, scholars and the media. Today more education scholars have applied soft power to educational research. For the key issues the current vocational education are facing: intense competition, running hard, unattractive and other issues, this paper analyzes the importance of soft power in vocational education and puts forward a number of recommendations from promoting reform and innovation of vocational education, rich campus culture and the implementation of brand strategy.
\end{abstract}

\section{Introduction}

Since 2002 the National Vocational Education Conference, the country conscientiously implement the "State Council on Vocational Education and vigorously promote the reform and development", vocational education has experienced a "quantity" of rapid development stage, and further expansion of education, economic and social services markedly increased, and yielded progress. But on the whole, vocational education is still the weak link in China's education, there is a concept behind vocational education, uneven development, to meet the social needs and other issues, including vocational education soft, uncoordinated construction of hard power, is becoming restricting key issues scientific Development of Vocational Education. Therefore, the current development needs to adapt to domestic and foreign, actively and steadily develop vocational education, their eyes and gaze turned connotation construction in a timely manner, and strive to build and enhance the "soft power" to enhance overall competitiveness, the new round of school competition, has the new era of higher vocational education and Higher Colleges of the most important issue.

\section{Significance of Enhancing Vocational Education Soft Power}

Vocational Education Soft Power is the Needed to Establish A Good Atmosphere. Vocational Education soft power is to establish vocational education in ideals and beliefs, and enhance students' self-confidence and entrepreneurial spirit; school governance culture unique school atmosphere, prompting vocational students can consciously self-restraint, effective integration of vocational education environment ; establish uplifting spirit and good campus atmosphere, through internalization into orderly study habits, thus forming a kind of intrinsic motivation strong incentives.

Vocational Education Soft Power is Needed to Enhanced Cohesion. The current vocational education is the most need is cohesion, and the current level of China's vocational education are high and low, poor management, low efficiency are objective problems, but more important is the influence of social diversity values, the presence of enough people together, the lack of sufficient cohesion, solidarity issue. Therefore, we must enhance the soft power construction by the charm and appeal of vocational education, and enhance solidarity and cohesion faculty, students and self-reliance of noble character and will, promoting vocational education to create a strong "magnetic field", seeks cohesion , together, with the force of effect.

Vocational Education Soft Power is Necessary to Develop Talents. Core vocational education is to train adapt to the times, service availability talent community. So in the final analysis the cause of vocational education is a human enterprise, we must adhere to the people-oriented, educating 
people to carry out all the work around. Constantly optimize the quality structure of teachers, vigorously develop talents at all levels; focus on educating people how to optimize personnel training programs, and strengthen information quality, innovation ability, for the construction of socialist culture with Chinese characteristics of various types of useful talents.

\section{Ways to Enhance the Soft Power of Vocational Education}

Reform of Vocational Education Innovation. Basic vocational education soft power is "innovation." China should implement the "Made in China" to "Created in China" and it has road long way to go forward, vocational education carries responsibilities and obligations incumbent upon. Currently, the development model of vocational education, although some Western practices borrowed from developed countries, but there are still some aspects incompatible "two-oriented society", therefore, the need for reform and innovation.

First, we must boldly carry out teaching model innovation. Higher Colleges should be based on social and economic development needs, and actively to society, to the market, investigation and analysis and academic research, combined with the characteristics of emerging industries and modern service industry to build for the current occupational characteristics, professional characteristics and economic demands of the professional structure , course structure, breaking professional restrictions, broaden their knowledge, so that students have the ability to multi-faceted employment. To re-improvement and develop teaching programs, adhere to the "wide caliber, thick foundation, living module, credit" course design principles, respect for student characteristics, advantages and tap their potential, promote diversification, "work" and "practical "," technology "of teaching methods, reform the traditional training model to school and classroom-centered personnel, increase student internships efforts to improve and innovative teaching models, evaluation methods, students focus on the overall quality and ability to adapt to the labor force changes in the market.

Secondly, we must pay attention to play to industry, companies in Vocational Education. School-enterprise cooperation training professional skilled personnel is the consensus of vocational education in China, but the current "cooperation" more superficial level, split off, that first school of theoretical teaching, practical training and then to the enterprise. However, because schools and businesses completely different management models, interest demands, culture and behavioral style, cooperation between the two is actually "dubious", students from the school to the enterprise, the education, different growth environment, it is difficult to adapt. To achieve "seamless" businesses, schools substantive, fusion, we can learn from the German vocational education in the "Dual System" and "apprenticeship" education, teaching at the same time in the enterprise and vocational schools. Students accepted in the enterprise 3-4 days a week of practice education, receiving 1-2 days of theoretical education at school. Play a leading role in corporate training, vocational schools only play the role of co-ordination and services. The task of teaching vocational schools mainly of professional counseling theory and practical training to improve student achievement in the enterprise, deepen and supplement general education task. Meanwhile, the school may also be implemented with the enterprise "order training" for enterprise oriented training personnel to enable the school to train students and business, industry to combine vocational pre-service training, so that students in the school's culture is more targeted, scientific and efficient, enhance the vitality of educational vocational schools, expand the depth and breadth of vocational education. To this end, higher vocational colleges need to strengthen communication with relevant government departments, to fight led by the administrative department of education between vocational institutions and enterprises to develop industry-academia cooperation policy, legal, financial and other support, to promote school education and business organic integration, the formation of schools, businesses, students of long-term mutual benefit and win-win cooperation mechanism.

Finally, build a modern management system to achieve scientific management. Faced with the new requirements of reform and development of vocational education, vocational colleges must actively implement the "standardized management and personality development coexistence" management philosophy, to establish a set of vocational education and social development to adapt and complete, scientific, functioning management mechanism. Have a strict management system, 
scientific incentive mechanism of competition, appraisal in place, clear incentives to form self-motivation, self-discipline, self-management; to adhere to sound management by objectives and levels of management, school management penetration, extending to schools, teachers and students in the development of every aspect of the management process to achieve step by step refinement, optimization, hierarchical management goal to reach, to promote scientific and standardized management of the school; people management system to achieve this, highlighting the people-oriented principle, emphasizing fertility people first, to achieve a combination of brains and hands, strengthen the practice, hands first, learning and employment simultaneously, two-pronged approach, employment-oriented. In this way, both from a strategic height, and specific solid, and gradually establish a high starting point, high level, to ensure the development of the modern school system school science and education for sustainable development.

Rich Campus Culture, Form the Core of the Concept. Campus culture is the soft power of school construction in stable core driving force, the campus culture of higher vocational colleges feature practical, professional and occupational. These features requires a comprehensive vocational education to students, the educational goals of sustainable development, focus on the students 'creative ability, practical ability, thinking ability, outstanding vocational skills training, training of highly skilled personnel, but also special attention to students' professional ethics education, establish professional culture with industry and occupational characteristics of property and services in the development of regional economy and society. Therefore, through the construction of campus culture, shaping positive school spirit, form the core values of the school philosophy, to lead the school forward spiritual culture, institutional culture to protect the school development, teachers and literacy curriculum rich culture, behavior culture highlight school grade, and gradually form alone Humanities and charm with a good environment. Specifically:

As the carrier campus environment, build classroom culture, dormitory culture, cultural corridor, canteen culture, fences culture, local cultural characteristics, creating a rich cultural atmosphere for education, to broaden students' development achievements to show the position;

After-school activities as the carrier, by conducting a variety of campus activities, the ideological and moral education, mental health education, Thanksgiving education, skills and education into the campus group activities, students, good schools and cultural heritage in the event. In addition, through various forms of skills competition, to improve students' skills, enthusiasm for learning, highlighting the vocational school characteristics and culture.

Facilitate the exchange of campus culture with magazine as a carrier. The accumulation of cultural heritage and distinctive magazine, embodied the essence of campus culture. Magazine's circulation, will produce a powerful centripetal force and cohesive force, so that all students have a strong sense of belonging and a sense of responsibility to promote and comprehensively improve the quality of teachers and students.

Demonstrate vocational school culture taking skills training for the carrier. Vocational and Technical Education in essence, is skills education for students' practical ability and professional competence have high demands, construction of campus culture must be combined with skills training, the formation of distinctive features.

Implement Brand Strategy and Enhance Attractiveness of Vocational Education. In recent years, with the rapid development of China's economy, vocational education also will be prosperity for the community to transport a lot of talent and it has become an important part of higher education. However, with the further development of market economy, society's increasingly high demand for talent. Coupled with college enrollment in recent years, the number of vocational colleges increase, competition among competition between vocational colleges, vocational colleges and colleges and universities is becoming increasingly fierce. In this case, the social demand point of vocational education, and I hope the point, the excitement gradually transferred to the school brand. Therefore, to maintain the advantages of higher vocational colleges under the new situation, meet the needs of the times, it is necessary to build their own brand characteristics. By improving the quality of, take the road of brand development, which is the inevitable choice of development strategy of higher vocational colleges. Brand development for technical colleges in addition to a 
good teaching quality, innovative educational model, excellent teachers, the characteristics of the campus culture, further comprising the following:

There are international brand awareness. Accession to the WTO not only has a significant impact on China's economic development, the impact on China's vocational talents training mode, goals and directions are also comprehensive. To this end, we must promptly adjust training objectives, as well as teaching, management tools, and international standards. International and domestic demand from the perspective of a combination of comprehensive training personnel, the personnel professional skills and overall quality can adapt to the needs of domestic enterprises, but also to meet the needs of international companies and organizations; both with international standards, global awareness and innovation, also has a certain international communication skills and competitiveness.

Have accurate brand positioning, brand and brand of professional courses. Comprehensive strength and characteristics of higher vocational colleges is mainly embodied by Brand Quality Institute. To make accurate positioning, with social demand, to develop comprehensive technology, can take the initiative to adapt to social and economic development, ethics good talents as the goal, through the cultivation of practical and high overall quality of talent highlighting their competitive advantages, to create a Vocational colleges with local characteristics and professional characteristics; To establish key professional, specialty as the core, to create a professional with local, national and international specialties, according to the region, the overall economic and social development needs of the industry, its positive related industries and additional industrial development, building a number of distinctive features, accurate positioning, embraced by the admissions Cape, graduating popular professional. In addition, higher vocational colleges to build brand must rely on the quality of education to achieve, and brand building is the specialty curriculum in higher vocational colleges foundation, therefore, in the current vocational college should be from their own reality, and actively participate in national and provincial level course under construction, to attract more high-quality programs, while building brand teacher works, and strive to improve the quality of teachers.

Good visibility and reputation. Good social assessment is vocational education to achieve brand-building is an important symbol. Means higher vocational colleges has gained the full confidence of more students and parents, and students are more willing to apply this vocational colleges, parents send their children into the peace of mind that vocational colleges, students and parents for school learning process and learning more assured quality, for future employment and employment conditions are no longer worried. At the same time, graduates have broad employment prospects, can be social, business and employers recognized, easier to maintain dominance in huge employment pressure competition, the chance to get promoted in future career development process, so as to community to create greater value and more wealth.

In short, enhancing the soft power of vocational education has become an important work to face the fierce competition looming under this market economy, for vocational colleges. Vocational colleges have to take strengthening measures in innovation management, special creation, enhance the quality and other aspects. They need to take people as the basis for democracy as the core to the system as the criterion and strive to build a modern management system to improve operating efficiency and open vocational education modernization dream door with soft power.

\section{References}

[1] W. Zhang. How to Enhance the Soft Power of Universities. China Education Daily. 2007, (6).

[2] Y.R. Di, G.B. Xin. Achieve Scientific Development of Vocational Education in China Reform and Creation Period. Continue the Reform and Innovation in Education and Research 2011, (6): 33.

[3] B. Liu. Innovative Vocational Education Reflections. Sichuan College of Education. 2005, (11): 106.

[4] L.J. Geng. Foreign Vocational Education and Enlightenment. 2009 Contemporary World, (4): 
59.

[5] G.C. Cui. Practice Vocational School Campus Culture Construction. China Agricultural Education .2006 (6): 24.

[6] T. Liang, H.R. Zhao. Brand Strategy on Higher Vocational College. Modern Business .2011, (26): 44.

[7] W.L. Chen. Brand Construction Strategy System Vocational Colleges. China Adult Education 2010, (2): 87. 